\title{
Növekvő népszerűség
}

\author{
Growing popularity
}

doi: 10.24365/ef.v61i1.574

A járványügyi vészhelyzet 12 ezerről 33 ezerre repítette az Egészségfejlesztés folyóirat látogatottságát. Ennek az lehet az oka, hogy a lakossági tájékoztatás egészségügyi főszereplője, Müller Cecília egyben a folyóirat felelős kiadója is, és a személyére irányuló internetes keresések a folyóirat honlapját is eredményül adták, de szerepet játszhatott még az otthoni munkavégzés részarányának növekedése is. Remélhetőleg a cikkek olvasottsága is hasonló emelkedést fog mutatni, és ezzel a lap még inkább hozzájárulhat a hazai népegészségügy szakmai színvonalának emeléséhez. A statisztikai adatokat, illetve a legolvasottabb és legnépszerübb cikkek rangsorát a megszokott ábra és táblázat mutatja be részletesen.
Aktuális lapszámunkban olvasható egy új tematikus válogatás, amit az egészségegyenlőtlenségek témája iránt érdeklődő szakembereknek ajánlunk, szakmai vezetőknek szóló 1 perces cikkünkben pedig az Az Európai Alkohol Akcióterv végrehajtását ismertetjük.

Első alkalommal publikálunk a lapban angol nyelvű közleményt, amely a Hepatitis B elleni iskolai védőoltást megelőző egészségnevelő program próbakutatásának eredményeiről számol be.

Várjuk hozzászólásaikat, javaslataikat a cikkekhez bejelentkezés után a weboldalon, és kövessék a lapot a facebook-on is.

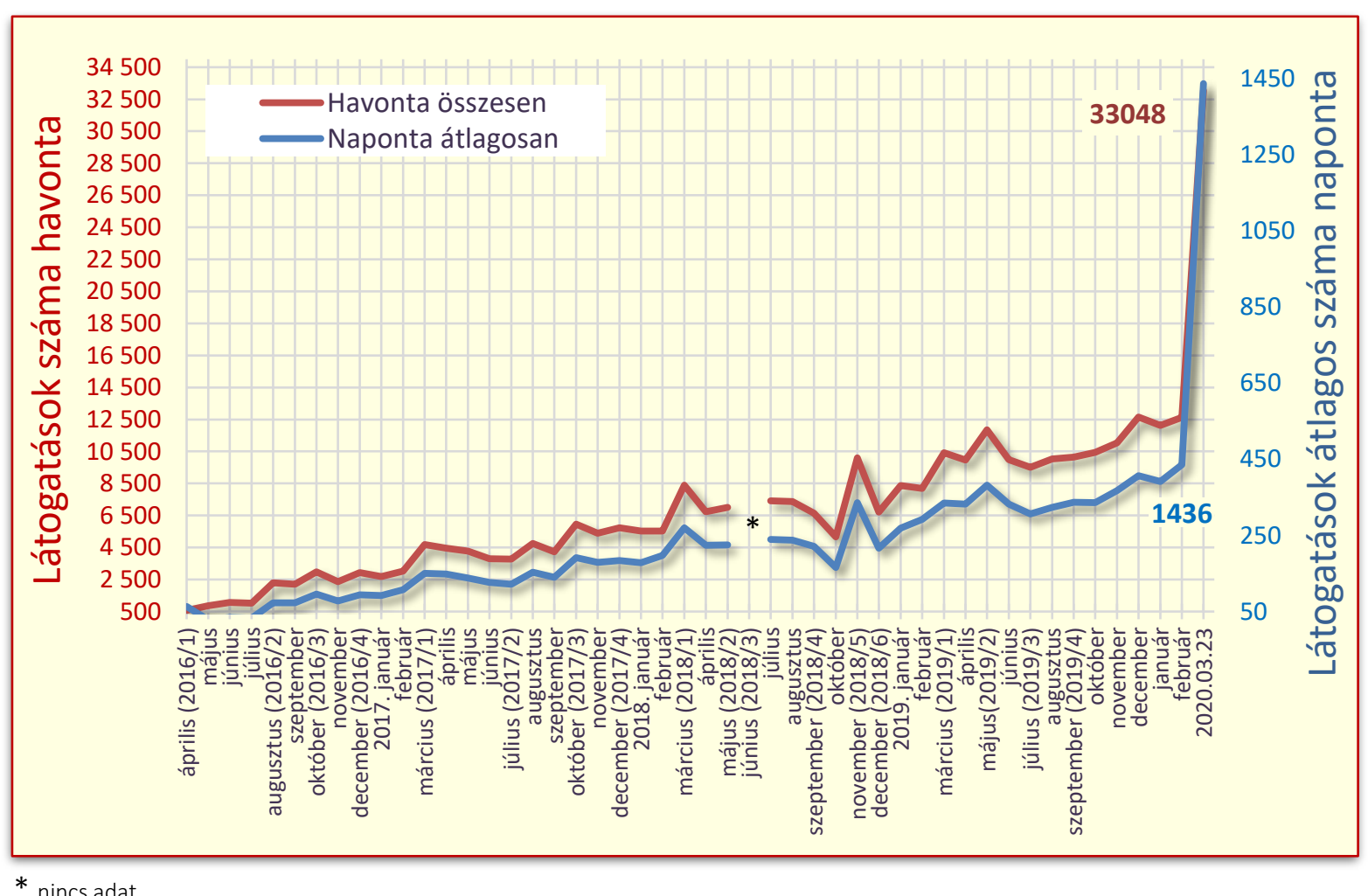




\begin{tabular}{|c|c|c|c|}
\hline $\begin{array}{l}\text { Megtekintések } \\
\text { száma }\end{array}$ & Közlemény címe & Szerzök & Lapszám \\
\hline \multicolumn{4}{|l|}{ ÖSSZEFOGLALÓ } \\
\hline 993 & Egészséges életmóddal kapcsolatos kutatások a hazai iskolákban & $\begin{array}{l}\text { Járomi É, Szilágyi K, } \\
\text { Vitrai J }\end{array}$ & 2016. 1. \\
\hline 859 & Hazai egészség-pillanatkép, 2017 & $\begin{array}{l}\text { Vitrai J, Bakacs M, Var- } \\
\text { sányi P }\end{array}$ & 2017. 4. \\
\hline 842 & A kortársbántalmazás (bullying) mint népegészségügyi probléma & $\begin{array}{l}\text { Várnai D, Zsíros E, Né- } \\
\text { meth Á }\end{array}$ & 2016. 4. \\
\hline 730 & A magyarországi egészségértés nemzetközi összehasonlításban & Koltai J, Kun E & 2016. 3. \\
\hline 726 & Az egészségműveltség definíciói & Csimadia P & 2016. 3. \\
\hline 682 & $\begin{array}{l}\text { Kortárs egészségfejlesztési programok gyermekek és fiatalok körében a hazai és a nemzet- } \\
\text { közi szakirodalom tükrében - Szisztematikus áttekintés }\end{array}$ & Lukács-Jakab Á et al. & 2018. 1. \\
\hline 624 & Családközpontúság és ágazatközi együttműködés a kora gyermekkori intervencióban & Kereki J, Kispéter L-né & 2018. 5. \\
\hline 594 & $\begin{array}{l}\text { A gyógytestnevelés jelentősége a szekunder rehabilitáció és egészségfejlesztés folyamatá- } \\
\text { ban, megújulásának szükségessége, irányai }\end{array}$ & Simon I, Kajtár G & 2018. 1. \\
\hline 592 & $\begin{array}{l}\text { Az egészségügyi ellátáshoz való hozzáférés területi egyenlőtlenségeinek vizsgálata az akut } \\
\text { miokardiális infarktus okozta halálozás adatainak felhasználásával }\end{array}$ & $\begin{array}{l}\text { Uzzoli A, Vitrai J, } \\
\text { Tóth G }\end{array}$ & 2017. 3. \\
\hline 592 & Egészségfejlesztő program középiskolások körében - Az alapállapot felmérés eredményei & Pénzes G, Bíró É & 2018. 4. \\
\hline \multicolumn{4}{|c|}{ TELUES KÖZLEMÉNY } \\
\hline 3408 & A csecsemőkori allergia-megelőzés korszerű irányelvei és lehetőségei & Réthy A & 2017. 1. \\
\hline 1929 & Egészségfejlesztési Irodák hálózata & Bezzegh P & 2016. 1. \\
\hline 1447 & Egészséges életmóddal kapcsolatos kutatások a hazai iskolákban & $\begin{array}{l}\text { Járomi É, Szilágyi K, } \\
\text { Vitrai J }\end{array}$ & 2016. 1. \\
\hline 1001 & Magyarország népegészségügyi rendszere és egészségfejlesztéssel foglalkozó szervezetei & Túri G et al. & 2018. 2. \\
\hline 925 & A fizikai aktivitás, mint egészségbefektetés & Gabnai Z et al. & 2019. 1. \\
\hline 906 & $\begin{array}{l}\text { Energiaital fogyasztási szokások és egészségtudatosság a felsőfokú képzésben résztvevő } \\
\text { hallgatók körében }\end{array}$ & $\begin{array}{l}\text { Dojcsákné Kiss-Tóth É, } \\
\text { Kiss-Tóth E }\end{array}$ & 2018.4. \\
\hline 795 & Hazai egészség-pillanatkép, 2017 & $\begin{array}{l}\text { Vitrai J, Bakacs M, Var- } \\
\text { sányi P }\end{array}$ & 2017. 4. \\
\hline 669 & OKOSTÁNYÉR ${ }^{\circledR}$ - új táplálkozási ajánlás a hazai felnőtt lakosság számára & Szűcs Zs & 2016. 4. \\
\hline 613 & $\begin{array}{l}\text { Megjelent az Iskoláskorú gyermekek egészségmagatartása kutatás legújabb felmérésének } \\
\text { nemzetközi jelentése }\end{array}$ & Németh Á & 2016. 1. \\
\hline 607 & A magyarországi egészségértés nemzetközi összehasonlításban & Koltai J, Kun E & 2016. 3. \\
\hline \multicolumn{4}{|l|}{ "ÉRDEKESSÉG" } \\
\hline 3,11 & A csecsemőkori allergia-megelőzés korszerű irányelvei és lehetőségei & Réthy A & 2017. 1. \\
\hline 2,41 & A fizikai aktivitás, mint egészségbefektetés & Gabnai Z et al. & 2019. 1. \\
\hline 1,66 & $\begin{array}{l}\text { Energiaital fogyasztási szokások és egészségtudatosság a felsőfokú képzésben résztvevő } \\
\text { hallgatók körében }\end{array}$ & $\begin{array}{l}\text { Dojcsákné Kiss-Tóth É, } \\
\text { Kiss-Tóth E }\end{array}$ & 2018. 4. \\
\hline 1,46 & Magyarország népegészségügyi rendszere és egészségfejlesztéssel foglalkozó szervezetei & Túri G et al. & 2018. 2. \\
\hline 1,36 & Egészségfejlesztési Irodák hálózata & Bezzegh P & 2016. 1. \\
\hline 1,16 & Krónikus betegségek előfordulásának gyakorisága Nyíregyháza felnőtt lakossága körében & Törő K et al. & 2019. 5. \\
\hline 1,10 & Kiskorúak egészségügyi ellátása Magyarországon betegjogi aspektusból & Feith JH & 2018. 5. \\
\hline 1,02 & Egészséges életmóddal kapcsolatos kutatások a hazai iskolákban & $\begin{array}{l}\text { Járomi É, Szilágyi K, } \\
\text { Vitrai J }\end{array}$ & 2016. 1. \\
\hline 0,96 & Hazai egészség-pillanatkép, 2017 & $\begin{array}{l}\text { Vitrai J, Bakacs M, Var- } \\
\text { sányi P }\end{array}$ & 2017. 4. \\
\hline 0,84 & $\begin{array}{l}\text { Serdülők étkezési szokásai az „egészséghit-modell”, illetve az énhatékonyság, az optimiz- } \\
\text { mus és az önkontroll tükrében }\end{array}$ & Szabó K, Pikó B & $\begin{array}{l}\text { 2019. } 5 . \\
\text { szám }\end{array}$ \\
\hline
\end{tabular}

